\title{
Analisis Kualitas Audit Aparat Pengawasan Internal Pemerintah Ditinjau Dari Kompetensi, Independensi, Dan Motivasi
}

\author{
Eri Kurniawan
}

Inspektorat Daerah Kota Blitar

Email: kurniawaneri324@gmail.com

\begin{abstract}
This research aim to examine the influence of competence, independence, and motivation of audit quality regional inspectorate officersand to determine the effect of competence, independence, and motivation to audit quality officials in Inspectorate Region of Blitar City. Competence, independence, and motivation of auditors to play a role in determining the quality of the audit will also affect the quality of the work of auditors. The purpose of this study was. This study uses primary data. The population in this study were all Blitar City Inspectorate officers who participated in the inspection tasks totaling 35 people, all members elected as members of the sample population (census). The data taken from questionaires distributed to respondents. The independent variable (independent) is competence, independence and motivation, while the bound variable (dependent) is the quality of audits. Data were analyzed using multiple linear regression analysis (multiple regretion). The results showed that the competence and motivation have a positive and significant impact on audit quality, while the independence of the variables do not have a significant impact on audit quality. Implications of these findings for efforts to realization of a quality audit is the need for providing motivation to the auditor about the urgency of a quality audit in addition to efforts to increase the competence through training.

Keywords: competence, independence, accountability, motivation and quality audit
\end{abstract}

\section{A. Latar Belakang Teoritis}

Mardiasmo (2001) menjelaskan bahwa akuntabilitas publik dengan transparansi dan pemberian informasi berartipemerintah memberikan pertanggungjawaban kepada masyarakat secara luas. Menurut Sunarsip (2001) pelaksanaan akuntabilitas sektor publik berhubungan dengan transparansi dan pemberian informasi kepada publik. Menurut Mardiasmo (2006)dan(Falah, 2006), Akuntabilitas baikvertikalmaupun horizontal mendukung terciptanya kepemerintahan yang baik adalah pengawasan, pengendalian dan pemeriksaanoleh unit pemeriksa yang merupakan bagian dari organisasi yang diawasi. Menurut Boynton (dalam Rohman, 2007), fungsi auditor internal adalah melaksanakan fungsi pemeriksaan internal. Mardiasmo (2002) menjelaskan bahwakelemahan audit pemerintahan di Indonesia, di antaranya tidak adanya indikator kinerja yang memadai.

Motivasi akan tinggi sampai tingkat di mana penghargaan yang diterima seorang individu atas kinerja yang tinggi memenuhi kebutuhan-kebutuhan dominan yang konsisten dengan tujuan-tujuan individualsertakemampuan (Robbins, 2008). DalamPeraturan Menteri Dalam Negeri
Nomor 44 Tahun 2008, meningkatkan kualitas auditor APIP dengan memberikan bimbingan teknis serta pendidikan dan pelatihan yang berkelanjutan, peningkatan infrastruktur penunjang bagi APIP.Good governance merupakan cara kekuasaan yang digunakan dalam mengelola berbagai sumber daya sosial dan ekonomi untuk pengembangan masyarakat (Mardoto, 2009 dalam Kuswanto, 2012). Tiga pilar good governance yang penting, yaitu: kesejahteraan rakyat, proses pengambilan keputusan, dan tata laksana pelaksanaan kebijakan (Prasetijo, 2009 dalam Kuswanto, 2012). Menurut Masyarakat Transparansi Indonesia (MTI), Good governance adalah pemahaman atas prinsip-prinsip Partisipasi masyarakat, Tegaknya supremasi hukum, Transparasi, Peduli , Berorientasi pada consensus, Kesetaraan, Efektifitas dan efisiensi, Akuntabilitas(Hardjasoemantri, 2003 dalam Kuswanto, 2012 ). Mulyawan (2009) mengemukakan pemimpin organisasi publik, sruktur organisasi dan sumberdaya manusianya baik maka akan tercipta good governance yang berpengaruh terhadap kinerja.

Yuanida (2010) menyimpulkan faktor-faktor good governance terbukti berpengaruh positif dan signifikan terhadap 
kinerja instansi pemerintah.Tiga proses Pengelolaan keuangan daerah tersebut adalah perencanaan, penatausahaan dan pelaporan (Afiah, 2009). Akuntansi, sebagai sistem informasi, berfungsi untuk mengidentifikasikan, mengumpulkan, memproses, dan mengkomunikasikan informasi ekonomi mengenai suatu entitas kepada berbagai orang yang berkepentingan (Bodnar, dalam Afiah, 2009). Sistem akuntansi yang dirancang secara baik, akan menjamin dilakukannya prinsip stewardship dan accountability dengan baik pula (Jones, dalam Afiah, 2009). Akuntansi sektor publik sedang mengalami proses untuk menjadi disiplin ilmu yang lebih dibutuhkan dan substansial keberadaannya (Mardiasmo, 2002). Perbedaan sifat dan karakteristik sektor publik dengan sektor swasta dapat dilihat dari tujuan organisasi, sumber pembiayaan, pola pertanggungjawaban, struktur kelembagaan, karakteristik anggaran, stakeholder, sistem manajemen/akuntansi (Haryanto, 2007).

Pengawasan terhadap penyelenggaran pemerintahan tersebut dapat dilakukan melalui pengawasan melekat, pengawasan masyarakat, dan pengawasan fungsional (Cahyat, 2004). Pengawasan atas penyelenggaraan pemerintahan daerah diatur Peraturan Pemerintah 79 Tahun 2005. Pengawasan ekstern pemerintah dilakukan oleh Badan Pemeriksa Keuangan, sedangkan pengawasan intern pemerintah dilakukan oleh Aparat Pengawasan Intern Pemerintah (Susmanto, 2008). Menurut Peraturan Menteri Negara Pendayagunaan Aparatur Negara nomor PER/05/M.PAN/03/2008, kegiatan utama APIP meliputi audit, reviu, pemantauan, evaluasi, dan kegiatan pengawasan lainnya berupa sosialisasi, asistensi dan konsultansi. Susmanto (2008), APIP melakukan pengawasan fungsional terhadap pengelolaan keuangan negara untuk membantu manajemen pemerintahan dalam pengendalian terhadap kegiatan unit kerjanya. Menurut Cahyat (2004), pengawasan terhadap pemerintah daerah dibagi pengawasan terhadap produk hukum dan kebijakan daerah, pelaksanaan penyelenggaraan pemerintahan daerah serta produk hukum dan kebijakan keuangan daerah.
Peran dari fungsi pengawasan untuk mengawal berbagai kegiatan dan program pemerintah daerah dalam penyelenggaraan pemerintahan daerah yang memenuhi prinsip tata kelola pemerintahan daerah yang baik dan dapat dipertanggungjawabkan.Bagi Kota Blitar, sebagai daerah yang memiliki julukan "Bumi Bung Karno", akuntabilitas akan audit yang berkualitas bagi pemerintahan yang akuntabel akan memotivasi aparat inspektorat untuk menggunakan dan meningkatkan kompetensi dan independensi yang dimilikinya. Sehingga perlu untuk diketahui pengaruh kompetensi, independensi, dan motivasi terhadap kualitas audit Inspektorat Daerah Kota Blitar.

\section{Kualitas Audit}

Kualitas audit merupakan sebuah konsep yang kompleks dan sulit dipahami, sehingga sering kali terdapat kesalahan dalam menentukan sifat dan kualitasnya.De Angelo (dalam Alim dkk, 2007) mendefinisikan kualitas audit sebagai probabilitas bahwa auditor akan menemukan dan melaporkan pelanggaran. Deis dan Groux (dalam Alim dkk, 2007) menjelaskan probabilitas menemukan pelanggaran tergantung pada kemampuan teknis dan probabilitas melaporkan pelanggaran tergantung pada independensi. Menurut Marxen (1990), dalam Sososutikno (2003), buruknya kualitas audit disebabkan oleh beberapa perilaku disfungsional. Government Accountability Office mendefinisikan kualitas audit sebagai ketaatan terhadap standar profesi dan ikatan kontrak selama melakdisanakan audit (Lowenshon et al, 2005). Standar audit menjadi bimbingan dan ukuran kualitas kinerja aditor (Messier et al, 2005). Selain kompetensi dan independensi, auditor juga harus memiliki tanggungjawab (akuntabilitas) terhadap profesinya dan alasan ditambahkan motivasi sebagai variabel baru (Reksohadiprodjo dalam Ardini, 2010). Audit yang dilakukan auditor dikatakan berkualitas jika memenuhi standar auditing dan standar pengendalian mutu (Elfarini, 2005). Pramono (2003), audit yang berkualitas dihasilkan oleh suatu proses audit yang sudah ditetapkan standarnya. Mardiasmo (2006) mengemukakan pemeriksaan merupakan kegiatan yang dilakukan oleh pihak yang memiliki kompetensi dan independensi untuk 
memeriksa. Lawenson et al. (2006) menyimpulkan bahwa spesialisasi auditor dan besarnya fee yang diterima auditor berpengaruh terhadap kualitas audit.

Menurut Peraturan Menteri Negara Pendayagunaan Aparatur Negara nomor PER/05/M.PAN/03/2008, pengukuran kualitas audit atas laporan keuangan, khususnya yang dilakukan oleh APIPmenggunakan Standar Pemeriksaan Keuangan Negara dalam Peraturan Badan Pemeriksa Keuangan Republik Indonesia Nomor 01 Tahun 2007. Audit harus dilaksanakan oleh yang memiliki keahlian dan pelatihan teknis yang cukup sebagai auditor (BPKP, 2015). Keahlian auditor menurut Tampubolon (2005) dapat diperoleh melalui pendidikan dan pelatihan yang berkelanjutan serta pengalaman yang memadai dalam melaksanakan audit. Auditor memiliki independensi dalam melakukan audit agar dapat memberikan pendapat atau kesimpulan yang apa adanya tanpa ada pengaruh dari pihak yang berkepentingan (BPKP, 2015). Audit yang berkualitas adalah audit yang dapat ditindaklanjuti oleh auditee.Indikatoryangdigunakanuntuk mengukur kualitas audit antara lain kualitas proses, apakah audit dilakukan dengan cermat, sesuai prosedur, sambil terus mempertahankan sikap skeptis.

\section{Kompetensi}

Webster's Ninth New Collegiate Dictionary (1983) dalam Sri Lastanti (2005) mendefinisikan kompetensi sebagai ketrampilan dari seorang ahli. Trotter (1986) dalam Saifuddin (2004), seorang yang berkompeten adalah orang yang dengan ketrampilannya mengerjakan pekerjaan dengan mudah, cepat, intuitif dan sangat jarang atau tidak pernah membuat kesalahan. Lee dan Stone (1995), kompetensi sebagai keahlian yang cukup yang secara eksplisit dapat digunakan untuk melakukan audit secara objektif. Adapun Bedard (1986) dalam Sri lastanti (2005) mengartikan keahlian atau kompetensi sebagai seseorang yang memiliki pengetahuan dan ketrampilan prosedural yang luas yang ditunjukkan dalam pengalaman audit. Hayes-Roth mendefinisikan keahlian sebagai pengetahuan tentang suatu lingkungan tertentu, pemahaman terhadap masalah yang timbul dari lingkungan tersebut, dan keterampilan untuk memecahkan permasalahan tersebut (Mayangsari, 2003). Dalam lampiran 2 SPKN, Pemeriksa yang ditugasi untuk melaksanakan pemeriksaan menurut Standar Pemeriksaan harus secara kolektif memiliki: pengetahuan, keahlian dan pengalaman. Menurut Tubbs (1992) dalam Mayangsari (2003) auditor berpengalaman memiliki keunggulan mendeteksi kesalahan, memahami kesalahan secara akurat, mencari penyebab kesalahan. Gibbins (1984) dalam Hernandianto (2002) menjelaskan pengalaman auditor bisa memperoleh pengetahuan dan mengembangkan struktur pengetahuannya.Kualitas audit menurut De Angelo (1981) auditor akan menemukan dan melaporkan pelanggaran pada sistem akuntansi klien. Harhinto (2004) pengaruh keahlian dan independensi terhadap kualitas audit,dimana keahlian diproksikan dengan pengalaman dan pengetahuan, sedangkan independensi diproksikan dalam lama ikatan dengan klien, tekanan dari klien dan telaah dari rekan auditor. Jika auditor kehilangan independensinya, maka laporan audit yang dihasilkan tidak sesuai dengan kenyataan yang ada sehingga tidak dapat digunakan sebagai dasar pengambilan keputusan (Supriyono, 1988).

Pengaruh kompetensi terhadap kualitas audit aparat Seorang auditor harus memiliki pengetahuan tentang Standar Pemeriksaan yang dapat diterapkan terhadap jenis pemeriksaan yang ditugaskan serta memiliki latar belakang pendidikan, keahlian dan pengalaman, pengetahuan umum tentang lingkungan entitas, program, dan kegiatan yang diperiksa. Kompetensiauditberupa penguasaan terhadap standar akuntansi danauditing, dan penguasaan terhadap objek audit (lampiran $2 \mathrm{SPKN}$ ). Kualitas audit merupakan kemungkinan auditor menemukan serta melaporkan pelanggaran. Kualitas audit menurut De Angelo (1981) adalah sebagai probabilitas bahwa auditor akan menemukan dan melaporkan pelanggaran pada sistem akuntansi klien. Kompetensi auditor adalah kemampuan auditor untuk mengaplikasikan pengetahuan dan pengalaman yang dimilikinya dalam melakukan audit sehingga auditor dapat melakukan audit dengan teliti, cermat, intuitif, dan obyektif. Oleh karena itu, dapat 
dipahami bahwa audit harus dilaksanakan oleh orang yang memiliki keahlian dan pelatihan teknis cukup sebagai auditor.Dalam audit pemerintahan, auditor dituntut untuk memiliki dan meningkatkan kemampuan atau keahlian bukan hanya dalam metode dan teknik audit, akan tetapi segala hal yang menyangkut pemerintahan seperti organisasi, fungsi, program, dan kegiatan pemerintah.

\section{Independensi}

Dalam SPKN yang berkaitan dengan pekerjaan pemeriksaan, organisasi pemeriksa dan pemeriksa harus bebas dalam sikap mental dan penampilan dari gangguan pribadi, ekstern, dan organisasi yang dapat mempengaruhi. Arens, et.al.(2000) independensi dalam pengauditan sebagai penggunaan cara pandang yang tidak bias dalam pelaksanaan pengujian audit, evaluasi hasil pengujian tersebut, dan pelaporan hasil temuan audit. Mulyadi (1992) mendefinisikan independensi sebagai keadaan bebas dari pengaruh, tidak dikendalikan oleh pihak lain, tidak tergantung pada orang lain. Menurut Messier et al (2005), independensi merupakan suatu istilah yang sering digunakan oleh profesi auditor. Independensi menghindarkan hubungan yang mungkin mengganggu obyektivitas auditor. BPKP (1998) mengartikan obyektivitas sebagai bebasnya seseorang dari pengaruh pandangan subyektif pihak-pihak lain yang berkepentingan sehingga dapat mengemukakan pendapat apa adanya. Menurut Holmes sebagaimana dikutip Supriyono (1988), independensi merupakan sikap bebas dari bujukan, pengaruh, atau pengendalian pihak yang diperiksa. Independensi auditor faktor yang penting menghasilkan audit yang berkualitas. (Supriyono, 1988). Harhinto (2004) bahwa besarnya tekanan dari klien dan lamanya hubungan dengan klien (audit tenure) berhubungan negatif dengan kualitas audit.Goleman (2001), Alim dkk. (2007) dan Elfarini (2007), menyimpulkan bahwa keahlian dan independensi auditor berpengaruh positif terhadap kualitas audit. Goleman (2001), dengan adanya motivasi maka seseorang akan mempunyai semangat juang yang tinggi untuk meraih tujuan dan memenuhi standar yang ada.
Gangguan pribadi yang disebabkan oleh hubungan dan pandangan pribadi mungkin mengakibatkan pemeriksa membatasi lingkup pertanyaan dan pengungkapan atau melemahkan temuan dalam segala bentuknya. Gangguan pribadi dari pemeriksa secara individu meliputi antaralainhubungan pertalian darah, kepentingan keuangan, pernah bekerja atau memberikan jasa, hubungan kerjasama, terlibat dalam kegiatan obyek pemeriksaan, danprasangka terhadap perorangan, kelompok, organisasi atau tujuan suatu program, yang dapat membuat pelaksanaan pemeriksaan menjadi berat sebelah(lampiran 2 SPKN).

Pengaruh independensi terbadap kualitas audit aparat

Independensi merupakan sikap auditor yang tidak memihak, tidak mempunyai kepentingan pribadi, dan tidak mudah dipengaruhi oleh pihak-pihak yang berkepentingan dalam memberikan pendapat atau simpulan, sehingga dengan demikian pendapat atau simpulan yang diberikan tersebut berdasarkan integritas dan objektivitas yang tinggi. Menurut Holmes sebagaimana dikutip Supriyono (1988), independensi merupakan sikap bebas dari bujukan, pengaruh, atau pengendalian pihak yang diperiksa.Independensi auditor merupakan salah satu faktor yang penting untuk menghasilkan audit yang berkualitas. Karena jika auditor kehilangan independensinya, maka laporan audit yang dihasilkan tidak sesuai dengan kenyataan yang ada sehingga tidak dapat digunakan sebagai dasar pengambilan keputusan (Supriyono, 1988). Dari penelitian yang dilakukan Harhinto (2004) diketahui bahwa besarnya tekanan dari klien dan lamanya hubungan dengan klien (audit tenure) berhubungan negatif dengan kualitas audit.

\section{Motivasi}

Terry (dalam Moekijat, 2002) mendefinisikan motivasi sebagai keinginan di dalam seorang individu yang mendorong ia untuk bertindak. Menurut Panitia Istilah Manajemen Lembaga Pendidikan dan Pembinaan Manajemen, motivasi adalah proses atau faktor yang mendorong orang untuk bertindak atau berperilaku dengan cara tertentu. Menurut Suwandi (2005), motivasi 
adalah pemaduan antara kebutuhan organisasi dengan kebutuhan personil. Partner audit dapat meningkatkan karir, serta peningkatan kompensasi atau penghasilan yang diperoleh, partner berkeyakinan akan memperoleh pengakuan positif, penghormatan, dan nama baik atau prestis dari masyarakat, serta peningkatan status sosial dalam masyarakat (Mardiasmo, 2002). Perubahan peraturan atau regulasi serta iklim politik disikapi secara hati-hati (ragu-ragu) oleh partner ketika akan menerima audit pemerintah (Mardiasmo, 2002).Dalam konteks studi psikologi, Abin Syamsuddin Makmun (2003) mengemukakan bahwa untuk memahami motivasi individu diantaranya durasi; frekuensi; persistensi; ketabahan, keuletan dan kemampuan dalam mengahadapi rintangan dan kesulitan; devosi; tingkat aspirasi; tingkat kualifikasi prestasi;) arah sikap terhadap sasaran kegiatan. Menurut Peraturan Menteri Negara Pendayagunaan Aparatur Negara (MENPAN) No. Per/05/M.Pan/03/2008 Auditor APIP harus mempunyai tingkat pendidikan formal minimal Strata Satu, kompetensi teknis, sertifikasi jabatan fungsional auditor (JFA), cermat dan seksama dan mematuhi Kode Etik. Sebagaimana dikatakan oleh Goleman (2001), hanya motivasi yang akan membuat seseorang mempunyai semangat juang yang tinggi untuk meraih tujuan dan memenuhi standar yang ada. Goleman (2001), motivasi yang akan membuat seseorang mempunyai semangat juang yang tinggi untuk meraih tujuan dan memenuhi standar yang ada.Rewards instrumentalities dengan segenap komponennya (penghargaan intrinsik dan ekstrinsik) berpengaruh positif terhadap motivasi partner auditor independen untuk melaksanakan audit pemerintah.

Pengarub motivasi terbadap kualitas andit aparat.

$$
\text { Sebagaimana dikatakan oleh }
$$

Goleman (2001), hanya motivasi yang akan membuat seseorang mempunyai semangat juang yang tinggi untuk meraih tujuan dan memenuhi standar yang ada. Dengan kata lain, motivasi akan mendorong seseorang, termasuk auditor, untuk berprestasi, komitmen terhadap kelompok serta memiliki inisiatif dan optimisme yang tinggi. Respon atau tindak lanjut yang tidak tepat terhadap laporan audit dan rekomendasi yang dihasilkan akan dapat menurunkan motivasi aparat untuk menjaga kualitas audit.

Penelitian ini mempunyai tujuan menganalisis pengaruh kompetensi aparat terhadap kualitas audit, menganalisis pengaruh independensi aparat terhadap kualitas audit dan menganalisis pengaruh motivasi aparat terhadap kualitas audit APIP di Inspektorat daerah Kota Blitar.

\section{B. Metode Penelitian \\ DesainPenelitian}

Penelitian yang dilakukan di Inspektorat Daerah Kota Blitar pada bulan Juli sampai dengan Agustus tahun 2018 adalah penelitian deskriptif kuantitatif. Sugiyono (2012) bahwa penelitian kuantitatif adalah bila data penelitian berupa angkaangka dan analisis menggunakan statistik. Populasi dalam penelitian ini adalah seluruh aparat Inspektorat Daerah Kota Blitar sebanyak 35 orang, karena jumlah populasi kurang dari 100 responden, maka metode pemilihan sampel yang digunakan adalah metode sensus, yaitu penyebaran kuesioner dilakukan pada semua populasi.

Uji validitas dilakukan untuk mengetahui apakah item-item yang tersaji dalam kuesioner benar-benar mampu mengungkapkan dengan pasti apa yang akan diteliti (Ghozali, 2006) dilakukan dengan uji korelasi Pearson Moment pada tingkat signifikansi 0,01 dan 0,02.Uji Reliabilitas untuk menguji konsistensi kuesioner dalam mengukur suatu konstruk yang sama atau stabilitas kuesioner jika digunakan dari waktu ke waktu (Ghozali, 2006) dengan metode internal consistency untuk mengukur reliabilitas dengan uji statistik Cronbach Alpha $(\alpha)$. Jika nilai koefisien alpha lebih besar dari 0,60 maka disimpulkan bahwa intrumen penelitian tersebut handal atau reliabel (Nunnaly dalam Ghozali, 2006).Instrumen merupakan alat ukur yang digunakan peneliti untuk mendapatkan data. Jawaban responden terhadap setiap butir pernyataan pada setiap kuisioner tersebut diberikan skala dengan menggunakan skala linkert. (Sugiyono, 2014).

\section{VariabelPenelitian}

Merujukpadabeberapa penelitian tentang kualitas audit yang pernah dilakukan, 
menyimpulkan temuan yang berbeda mengenai faktor yang mempengaruhi kualitas audit. Lawenson et al. (2006) menyimpulkan bahwa spesialisasi auditor dan besarnya fee yang diterima auditor berpengaruh terhadap kualitas audit. Sementara itu dalam penelitian Alim dkk. (2007) dan Elfarini (2007), diperoleh kesimpulan bahwa keahlian dan independensi auditor berpengaruh positif terhadap kualitas audit. Goleman (2001), hanya motivasi yang akan membuat seseorang mempunyai semangat juang yang tinggi untuk meraih tujuan dan memenuhi standar yang ada.Kualitas audit merupakan probabilitas bahwa auditor akan menemukan dan melaporkan pelanggaran pada sistem akuntansi pemerintah dengan berpedoman pada standar akuntansi dan standar audit yang telah ditetapkan. Kompetensi dalam pengauditan merupakan pengetahuan, keahlian, dan pengalaman yang dibutuhkan auditor untuk dapat melakukan audit secara objektif, cermat dan seksama. Independensi dalam pengauditan merupakan penggunaan cara pandang yang tidak bias dalam pelaksanaan penguijan audit, evaluasi hasil pengujian tersebut, dan pelaporan hasil temuan audit. Motivasi dalam pengauditan merupakan derajat seberapa besar dorongan yang dimiliki auditor untuk melaksanakan audit secara berkualitas

Dalam penelitian ini, variabel dependen yang digunakan adalah kualitas audit Inspektorat dalam pengawasan keuangan daerah sedangkan variabel independennya terdiri dari kompetensi auditor, independensi auditor, dan motivasi auditor.

\section{MetodeAnalisis}

Analisa Deskriptif digunakan untuk menggambarkan masing-masing variabel baik variabel bebas maupun variabel terikat serta karakteristik responden (Sugiyono, 2015). Uji normalitas untuk menguji apakah dalam model regresi, variabel dependen dan independen keduanya mempunyai distribusi normal atau tidak (Ghozali, 2006). Untuk Uji K-S yakni jika nilai hasil Uji K-S > dibandingkan taraf signifikansi 0,05 maka sebaran data tidak menyimpang dari kurva normalnya itu uji normalitas.Uji Multikolinieritas untuk mendeteksi gejala korelasi antara variabel independen yang satu dengan variabel independen yang lain. Uji Multikolinieritas melihat VIF (Variance Inflation Factors) dan nilai tolerance. Jika VIF $>10$ dan nilai tolerance $<0,10$ maka terjadi gejala Multikolinieritas (Ghozali, 2006).Uji heteroskedastisitas untuk menguji apakah terjadi ketidaksamaan variance dari residual satu pengamataan ke pengamatan yang lain tetap, atau disebut homoskedastisitas.Melalui uji Glesjer, jika probabilitas signifikansi masing-masing variabel independen $>0,05$, maka dapat disimpulkan tidak terjadi heteroskedastisitas dalam model regresi (Ghozali, 2006).Pengujian hipotesis dilakukan dengan menggunakan model analisis regresi berganda bertujuan untuk memprediksi berapa besar kekuatan pengaruh variabel independen terhadap variabel dependen. Persamaan regresinya $\mathrm{Y}=\beta 0+\beta 1 \mathrm{X} 1+\beta 2 \mathrm{X} 2+\beta 3 \mathrm{X} 3$. Uji $F$ dapat pula dilakukan dengan membandingkan nilai Fhitung dan Ftabel. Jika Fhitung $>$ F tabel (n-k-1), maka $\mathrm{Ha}$ diterima. Jika Fhitung $<$ F tabel (n-k-1), maka Ha ditolak.Uji t digunakan untuk mengetahui pengaruh masing-masing variabel independen terhadap variabel dependen. Kriteria pengujian yang digunakan adalah jika $\mathrm{p}$ value $<0,05$, maka Ha diterima dan jika $\mathrm{p}$ value $>$ 0,05 , maka Ha ditolak.

Kerangka Pikir Penelitian

\section{INDEPEDENSI}

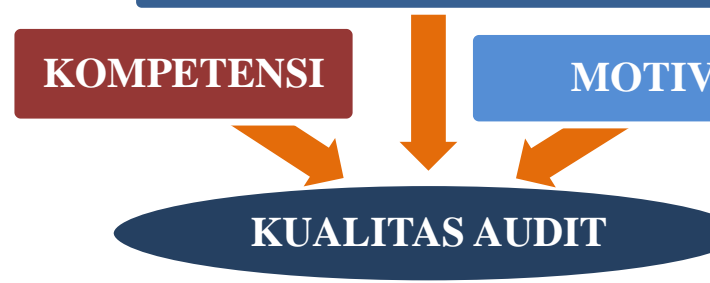

\section{Hasil Penelitian Dan Implikasi}

Berdasarkan Peraturan Walikota Blitar Nomor: 56 Tahun 2016 Inspektorat Kota Blitar merupakan unsur pengawas penyelenggara pemerintahan daerah, dipimpin seorang Inspektur yang dalam melaksanakan tugasnya bertanggungjawab kepada Walikota melalui Sekretaris Daerah untuk membantu wali kota membina dan 
mengawasi pelaksanaan urusan pemerintahan yang menjadi kewenangan daerah dan tugas pembantuan oleh perangkat daerah.

Dari hasil uji validitas yang dilakukan dengan bantuan program SPSS menunjukkan bahwa koefisien korelasi pearson moment untuk setiap item butir pernyataan dengan skor total variabel kualitas audit, kompetensi, independensi, dan motivasi signifikan pada tingkat signifikansi 0,01. Dapat diinterpretasikan bahwa setiap item indikator instrumen untuk kualitas audit tersebut valid. Hasil perhitungan uji reliabilitas menunjukkan bahwa nilai Cronbach Alpha $(\alpha)$ untuk masing-masing variabel adalah lebih besar dari 0,60, dapat disimpulkan bahwa item-item instrumen untuk masing-masing variabel adalah reliabel (Nunnally dalam Ghozali, 2006).Semua indikator dari variabel conscientiousness dan risk tolerance dapat digunakan dalam pengolahan data selanjutnya. Uji normalitas data dalam penelitian ini menggunakan Uji Kolmologorov-Smirnov (Uji K-S) .

Nilai KS sebesar 1,001. Nilai ini tidak signifikan pada 0,05 (karena nilai $\mathrm{P}=0,269$, lebih besar dari 0,05). Sebaran data tidak menunjukkan penyimpangan dari kurva normalnya, berarti sebaran data telah memenuhi asumsi normalitas, menunjukkan bahwa model regresi layak dipakai karena memenuhi asumsi normalitas.Uji multikolinieritas nilai tolerance $>0,1$ dan VIF 10, maka dinyatakan tidak ada korelasi sempurna antar variabel independen dan sebaliknya. Angka tolerance dari variabel independen kompetensi dan independensi mempunyai nilai tolerance lebih dari 0,10 berarti tidak ada korelasi antar variabel indpenden yang nilainya lebih dari 95\%. Hasil perhitungan nilai Variance Inflantion Factor (VIF) menunjukkan tidak ada satupun variabel independen yang memiliki nilai VIF lebih dari 10. Disimpulkan dalam model regresi tidak terjadi multikolinieritas antar variabel independen tersebut.Pengujian heteroskedastisitas menyatakan bahwa tidak terjadi heteroskedastisitas dalam model regresi.Hasil uji Glesjer menunjukkan bahwa probabilitas signifikansi semua variabel independen di atas tingkat kepercayaan 0,05 bahwa model regresi ini memenuhi asumsi heteroskedastisitas, pada model regresi ini variasi data homogen, terjadi kesamaan varians dari residual satu pengamatan ke pengamatan yang lain.

Berdasarkan output model summary, besarnya adjusted R2 (koefisien determinasi yang telah disesuaikan) adalah 0,722. Nilai ini menunjukkan bahwa $72,2 \%$ variasi kualitas audit dapat dijelaskan oleh variasi dari ketiga variabel independen yaitu kompetensi, independensi, dan motivasi, sedangkan sisanya $27,8 \%$ dijelaskan oleh sebab lain di luar model. Standard Error of Estimate 1,971 apabila dibandingkan dengan standard deviation variabel dependen kualitas audit 3,736 adalah lebih kecil.Hasil uji simultan ANOVA atau $F$ test diperoleh nilai Fhitung sebesar 30,381 dengan probabilitas 0,000. Karena probabilitas jauh lebih kecil dari nilai signifikan 0,05 , maka model regresi dapat digunakan untuk memprediksi kualitas audit atau dapat dikatakan bahwa kompetensi, independensi, dan motivasi aparat inspektorat secara simultan berpengaruh terhadap kualitas audit.Jika Fhitung $>$ Ftabel maka secara simultan variabel-variabel independen berpengaruh signifikan terhadap variabel dependen. Pada taraf $\alpha=0,05$ dengan derajat kebebasan pembilang/df1 (k) $=3$ (jumlah variabel independen) dan derajat kebebasan penyebut/df2 $(\mathrm{n}-\mathrm{k}-1)=31$, diperoleh nilai Ftabel 2,911. Nilai Fhitung 30,381 lebih besar dari nilai Ftabel (2,911). Bahwa variabel kompetensi, independensi, dan motivasi secara bersama-sama mempengaruhi variabel kualitas audit.

HASIL OLAHAN REGRESI BERGANDA

\begin{tabular}{|c|c|c|c|}
\hline Model & $\begin{array}{c}\text { KoefisienRegresi } \\
B\end{array}$ & Hipotesis & t hitung \\
\hline Constant & 3,187 & & \\
\hline Kompetensi & 0,294 & $\overline{\mathrm{H}_{1}}$ & 2,183 \\
\hline Independensi & 0,226 & $\mathrm{H}_{2}$ & 1,587 \\
\hline Motivasi & 0,481 & $\mathrm{H}_{3}$ & 3,259 \\
\hline $\mathrm{R}$ & 0,864 & \multirow{8}{*}{\multicolumn{2}{|c|}{$\begin{array}{ll}* & \text { Signifikanpada } \\
* * & \text { Signifikanpada } \\
* * * & \text { Signifikanpada } \\
\text { **** } & \text { Tidaksignnifika }\end{array}$}} \\
\hline R Square & 0,746 & & \\
\hline Adjusted R Square & 0,722 & & \\
\hline $\mathrm{t}$ & 1,024 & & \\
\hline F hitung & 30,381 & & \\
\hline Sig. & 0,314 & & \\
\hline Sig F & 0,000 & & \\
\hline $\mathrm{n}$ & 35 & & \\
\hline
\end{tabular}


dan nilai thitung 2,183. Nilai koefisien regresi ini signifikan pada tingkat signifikansi 0,05 dengan $\mathrm{p}$ value sebesar 0,037 . Nilai ttabel pada taraf signifikansi $5 \%$ dan df (derajat kebebasan) $\mathrm{n}-\mathrm{k}-1=31$ adalah 2,040. Nilai thitung 2,183 > ttabel 2,040. Variabel kompetensi berpengaruh positif dan signifikan terhadap kualitas audit pada taraf signifikansi $5 \%$ atau hipotesa diterima.Nilai koefisien regresi variabel kompetensi aparat inspektorat adalah 0,226 dan nilai thitung 1,587. Nilai koefisien regresi ini tidak signifikan pada tingkat signifikansi 0,05 dengan $\mathrm{p}$ value sebesar 0,123 . Hasil ini menjelaskan bahwa nilai koefisien regresi variabel independensi aparat inspektorat berpengaruh positif terhadap kualitas audit, namun demikian pengaruh tersebut tidak signifikan.Nilai ttabel pada taraf signifikansi $5 \%$ dan df (derajat kebebasan) n-k-1 = 31 adalah 2,040. Nilai thitung 1,587 < ttabel 2,040 sehingga perubahan atau variasi variabel independensi tidak akan diikuti oleh variasi kualitas audit. Variabel independensi tidak berpengaruh signifikan terhadap kualitas audit pada taraf signifikansi $5 \%$ atau hipotesa ditolak.Nilai koefisien regresi variabel motivasi aparat inspektorat adalah 0,481 dan nilai thitung 3,259. Nilai koefisien regresi ini signifikan pada tingkat signifikansi 0,05 dengan $\mathrm{p}$ value sebesar 0,003 . Nilai ttabel pada taraf signifikansi $5 \%$ dan $\mathrm{df}$ (derajat kebebasan) n-k-1 = 31 adalah 2,040. Nilai thitung 3,259 > ttabel 2,040. Variabel motivasi berpengaruh positif dan signifikan terhadap kualitas audit pada taraf signifikansi $5 \%$ atau hipotesa diterima. Persamaan regresi dalam penelitian ini adalah: $\mathrm{Y}=3,187+$ 0,294X1 + 0,226X2 + 0. 481X3. Dari persamaan regresi tersebut dapat dijelaskan nilai kostanta yang tercantum sebesar 3,187 dapat diartikan jika variabel Kompetensi, Independensi, dan Motivasi nilainya adalah nol, maka Kualitas Audit nilainya adalah 3,187. Nilai Fhitung lebih besar dari pada Ftabel yaitu 30,381>3,886 dan nilai signifikansi sebesar 0,000 lebih kecil dari pada tingkat signifikansi $0,05 \quad(0,000<$ $0,05)$.Variabel kompetensi, independensi dan motivasi berpengaruh positif dan signifikan terhadap kualitas audit pada taraf signifikansi 5\% atau dengan kata lain $\mathrm{H} 4$ diterima.

\section{Pembahasan}

Pengarub Kompetensi terbadap Kualitas Audit

Kompetensi berpengaruh signifikan terhadap kualitas audit. Hasil pengujian statistik menunjukkan bahwa nilai koefisien regresi variabel kompetensi adalah 0,294. Nilai ini signifikan pada tingkat signifikansi 0,05 dengan $p$ value 0,037 . Hasil ini didukung oleh hasil perhitungan nilai t hitung 2,183 > t tabel 2,040. Hal ini menunjukkan bahwa kompetensi berpengaruh signifikan terhadap kualitas audit.

Hasil pengujian hipotesis ini sejalan dengan pendapat De Angelo bahwa kemungkinan (probability) dimana auditor akan menemukan salah saji tergantung pada kualitas pemahaman auditor (kompetensi). Gibbin's dan Larocque's (1990) juga menunjukkan bahwa kepercayaan, komunikasi, dan kemampuan untuk bekerjasama adalah unsure penting bagi kompetensi auditHasil penelitian ini jugamendukungdansejalan dengan hasil penelitian yang dilakukan oleh Harhinto (2004) Fauziah (2017)Partanadi (2016)Togar (2016) Zulian (2016)Permatasari, Wasito, Andriana (2016)(Mardisar dan Sari , 2007. Murtanto (1998) dalam Mayangsari (2003)Mariyanto (2017) yang menyakataknbahwavariabel

kompetensiberpengaruh signifikan terhadap kualitas audit.

Hasil tersebut dapat dipahami bahwa untuk meningkatkan kualitas audit, seorang auditor sangat bergantung pada tingkat kompetensinya. Jika auditor memiliki kompetensi yang baik maka auditor akan dengan mudah melakukan tugas-tugas auditnya dan sebaliknya jika rendah maka dalam melaksanakan tugasnya, auditor akan mendapatkan kesulitan-kesulitan sehingga kualitas audit yang dihasilkan akan rendah pula..

Pengaruh Independensi terbadap Kualitas Audit Independensi tidakberpengaruh signifikan terhadap kualitas audit. Hasil pengujian statistik menunjukkan bahwa nilai koefisien regresi variabel independensi adalah 0,226 . Nilai ini signifikan pada tingkat signifikansi 0,05 dengan $p$ value 0,123 . Hasil ini didukung oleh hasil perhitungan nilai $\mathrm{t}$ hitung 1,587 $<\mathrm{t}$ tabel 2,040. Hal ini menunjukkan bahwa independensi tidak berpengaruh signifikan terhadap kualitas audit. 
Hasil pengujian hipotesis ini tidak sejalan dengan pendapat De Angelo bahwa kemungkinan dimana auditor akan melaporkan salah saji tergantung pada independensi auditor. Hasil penelitian ini mendukungdansejalan dengan Mayangsari (2003) Samelson et al.(2006) Alim dkk (2007) Gustiawan (2015) Nurulpa (2014) Wirasuaiti, Suliandati, Supriyono (1988) Herawati (2014) yang menyimpulkan bahwa independensi tidak mempunyai hubungan dengan kualitas audit. Hipotesis penelitian ini tidak berhasil dibuktikan, diduga karena independensi aparat Inspektorat Daerah Kota Blitar masih terpengaruh dengan penentu kebijakan dan sering adanya mutasi antar satuan kerja perangkat daerah. Akibatnya, meskipun aparat acapkali mendapat fasilitas dari auditee, namun aparat tetap menganggap bahwa audit yang baik tetap harus dilaksanakan.Ikatan kepentingan keuangan dan hubungan usaha dengan klien secara signifikan mempengaruhi independensi penampilan akuntan publik.Auditor yang independen memberikan pendapat lebih tepat dibandingkan auditor yang tidak independen.

Pengaruh Motivasi terhadap Kualitas Audit

Motivasiberpengaruh signifikan terhadap kualitas audit. Hipotesis variabel motivasi (X3) yang diproksikan dalam ketengguhan, keuletan, dan konsistensi, mempunyai pengaruh yang signifikan terhadap kualitas audit. Hasil pengujian statistik menunjukkan bahwa nilai koefisien regresi variabel kompetensi adalah 0,481. Nilai ini signifikan pada tingkat signifikansi 0,05 dengan $p$ value 0,003 . Hasil ini didukung oleh hasil perhitungan nilai t hitung 3,259 > t tabel 2,040. Hal ini menunjukkan bahwa motivasi berpengaruh signifikan terhadap kualitas audit.

Hal ini mendukungdansejalan dengan yang dikatakan oleh Goleman (2001) bahwa hanya motivasi yang akan membuat seseorang mempunyai semangat juang yang tinggi untuk meraih tujuan dan memenuhi standar yang ada. Respon atau tindak lanjut yang tidak tepat terhadap laporan audit dan rekomendasi yang dihasilkan akan dapat menurunkan motivasi aparat untuk menjaga kualitas audit.(Ardini 2010).Indah (2010) Andini (2010) Effendy (2010) Ramadhanis (2012) Nirwana (2014) Nopitasari (2015)penelitiannya menyimpulkan bahwa kompetensi dan motivasi berpengaruh positif dan signifikan terhadap kualitas audit, sedangkan variabel independensi tidak mempunyai pengaruh yang signifikan terhadap kualitas audit.

\section{Implikasi}

Hasilpenelitianini

mempunyaiimplikasipada aparat inspektorat daerahbahwasecaraempiris adanya pengaruh kompetensi dan motivasi terhadap kualitas audit yang dilaksanakan oleh aparat inspektorat daerah menunjukkan bahwa penguasaan terhadap metode dan teknik audit serta segala hal yang menyangkut pemerintahan seperti organisasi, fungsi, program, dan kegiatan pemerintah akan dapat ditunjang oleh motivasi bahwa tercapainya tujuan pelaksanaan audit merupakan kebutuhan organisasi inspektorat daerah sekaligus kebutuhan personil aparat inspektorat daerahagar terus menjaga dan meningkatkan kompetensi aparat melalui pemberian pelatihan-pelatihan serta kesempatan untuk mengikuti kursus-kursus atau peningkatan pendidikan profesi. Dan tidak hanya itu, penentu kebijakan juga tidak boleh melalaikan motivasi yang dimiliki aparat dalam menjalankan tugas audit.

Pengaruh kompetensi dan motivasi terhadap kualitas audit yang dilaksanakan oleh aparat inspektorat daerah. Secara teoritis, hal ini mendorong arah riset selanjutnya untuk lebih spesifik meneliti halhal apa saja yang dapat mempengaruhi tingkat motivasi aparat inspektorat daerah.Untuk mempertahankan independensinya, inspektorat harus mendapatkan dukungan dari pemerintah daerah sehingga para pejabat pengawas pemerintahan ini (auditor inspektorat) akan mendapatkan kerjasama dari perangkat daerah yang menjadi auditinya dan bebas melaksanakan pekerjaan auditnya dari gangguan-gangguan yang dapat menghambat atau mempengaruhi pekerjaan audit. Peraturan Pemerintah Republik Indonesia Nomor 41 Tahun 2007 Tentang Organisasi Perangkat Daerah, dinyatakan bahwa Inspektur secara teknis administratif mendapat pembinaan dari sekretaris daerah, namun Inspektur tetap bertanggung jawab secara langsung dan melaporkan hasil 
pengawasannya kepada kepala pemerintah daerah. Sehingga peran Inspektorat daerah lebih mengedepankan pembinan dan pengawasan sehingga tidak bisa secara maksimal dan independen mencegah pelaggaran peraturan perundang-undangan yang dilakukanolehpimpinandaerah.Fungsi pengawasan di lingkungan pemerintahan daerah, bahwa inspektur atau kepala inspektorat melaporkan hasil pengawasannya kepada kepala daerah sebagai tingkatan pimpinan tertinggi dalam penyelenggaraan pemerintahan daerah

\section{Kesimpulan dan Rekomendasi}

Berdasarkan hasil penelitian dapat diambil kesimpulan bahwa:

1. Kompetensi, independensi, dan motivasi secara simultan berpengaruh terhadap kualitas audit yang dilaksanakan oleh aparat Inspektorat Daerah Kota Blitar.

2. Kompetensi berpengaruh positif terhadap kualitas audit, sehingga semakin baik tingkat kompetensi, maka akan semakin baik kualitas audit yang dilakukannya.

3. Independensi tidak berpengaruh secara signifikan terhadap kualitas audit, sehingga independensi yang dimiliki tidak menjamin karena dibatasi oleh kedudukan secara organisasi dan fungsi mengedepankan pembinaan.

4. Motivasi berpengaruh positif terhadap kualitas audit, sehinggamotivasi membuat seseorang mempunyai semangat juang yang tinggi untuk meraih tujuan dan memenuhi standar yang ada.

\section{E. Daftar Pustaka}

